\title{
The Consequences of Parental Divorce on the Life Course Outcomes of Canadian Children
}

\author{
Valerie Martin \\ Department of Sociology \\ McGill University \\ Montreal, Quebec, Canada \\ Melinda Mills \\ Department of Sociology \\ University of Groningen \\ The Netherlands \\ Céline Le Bourdais \\ Department of Sociology \\ McGill University \\ Montreal, Quebec, Canada
}

\begin{abstract}
Applying the theory of the intergenerational transmission of divorce, this paper examines the consequences of parental divorce on three aspects of the life course of children: union formation, nonmarital fertility, and marital dissolution. The 1995 Canadian General Social Survey (GSS) is used to estimate various regression models (Cox proportional hazards). Results show that children of divorced parents have a significantly higher likelihood to have births outside of marriage, enter into cohabiting unions, and to experience higher levels of divorce. Throughout the paper, attention is placed on the markedly different behaviour observed in Quebec compared to elsewhere in Canada.
\end{abstract}

Key Words: Parental divorce, intergenerational transmission of divorce, event history analysis, Canada, Quebec. 
Martin, Valerie, Melinda Mills and Céline LeBourdais

\section{Résumé}

S'inspirant de la théorie de la transmission intergénérationnelle du divorce, cet article examine les conséquences d'un divorce parental en regard de trois aspects de la trajectoire de vie des enfants rendus à l'âge adulte: la formation du couple, l'arrivée d'une naissance hors mariage et le risque de rupture du mariage. Les données provenant de l'Enquête sociale générale sur la famille, réalisée par Statistique Canada en 1995, sont analysées à partir de différents modèles de régression (analyse des transitions ou modèle de Cox). Les résultats montrent que les enfants venant d'une famille divorcée sont plus à risque que les enfants venant d'une famille intacte d'avoir une naissance hors mariage, de former une union libre et de divorcer une fois mariés. Une attention particulière est portée aux différences de comportements qui séparent le Québec du reste du Canada.

Mots clés: divorce parental, transmission intergénérationnelle du divorce, analyse des transitions, Canada, Québec.

\section{Introduction}

Between 1971 and 1990, the crude divorce rate in Canada more than doubled, showing a 113 per cent rate of change (United Nations, 1997). In 2000, the proportion of Canadian marriages expected to end in a divorce before the $30^{\text {th }}$ wedding anniversary reached 38 per cent. This number is even higher in Quebec, where 47.4 per 100 marriages ended in divorce by this time (Statistics Canada, 2002). These high levels of divorce raise the question of what happens to the children of divorced parents, now that they are reaching adulthood. The aim of this paper is to study the consequences of divorce for the children of divorcees in Canada on three dimensions of the life course: union formation, nonmarital fertility behaviour and marital dissolution.

A central question is: Will we observe similar life course patterns between the 'children of divorce' and those raised in 'intact' families? The first research question asks whether parental divorce shapes the partnership formation behaviour of children from these broken marriages. Here we examine whether these children enter into partnerships at an earlier age and whether children experiencing a parental break-up are more likely to cohabit, offering an alternative explanation for increases in cohabitation in Canada, and particularly in Quebec. Out of the 10 
provinces, Quebec has consistently held the highest rate of cohabitation, which was 24 per cent of all unions in 1996 (Statistics Canada, 1997b). This was considerably higher than in the English speaking provinces, such as Prince Edward Island where only 9 per cent of all unions were cohabitation (Wu, 2000: 47). A second question asks: Are children of divorcees more likely to have births outside of marriage? Third, are children of divorcees more inclined to divorce compared to children from intact families? Finally, we ask whether the impact of parental divorce differs in Quebec in comparison with the rest of Canada.

After defining the family types used in this study, the following section outlines the theory of intergenerational transmission of behaviour approached from three different perspectives. This is then followed by a brief description of the data and methods used in this analysis. Several event history models are applied to the 1995 General Social Survey (GSS) in order to examine the varying effects of parental divorce on children's behaviour. The results are then presented, followed by a discussion of the broader implications of these findings.

\section{Defining Family Types}

Before delving into a discussion of the impact of parental divorce, it is necessary to first define the various family types examined within this study. Following Le Bourdais et al. (2000), an 'intact' family refers to an ongoing union in which both parents had their first children; the children therefore did not experience the breakdown of their family. A 'divorced' family is defined as one in which previously legally married parents experienced either a separation or divorce. The break-up of an intact family can also result from the death of one parent. In this case, we included orphans in our study in order to control for whether the transmission effects are related to divorce or whether they are attributed to the circumstances of growing up in a single-parent family.

Children whose parents lived in an intact or dissolved common-law union are not taken into account; common-law families were quite different from married families, particularly in earlier historical periods (see Mills, 2000). Furthermore, most studies focussing on the theory of the "intergenerational transmission of divorce"1 were conducted in the United States and restricted to the analysis of married parents (see Bumpass et al., 1995). By contrast, common-law families have received far more attention in Canadian family research. However, as our purpose is to examine the impact of the theory of the intergenerational transmission of divorce in Canada, we decided to focus solely on married families and not to take into account the conjugal histories of common-law parents. 


\section{Intergenerational Transmission of Behaviour: A Theoretical Framework}

The general framework of the theory of the intergenerational transmission of behaviour is used to understand how parental divorce shapes various aspects of children's life courses. Our study extends the analysis beyond the intergenerational transmission of divorce to also include impacts in other realms of the life course, such as union formation and parenthood. The theory itself consists of three main frameworks: 1) stress theory; 2) socialization theory; and, 3) the theory of economic deprivation. This section discusses each of these approaches in detail, accompanied by the development of specific research hypotheses.

\section{Stress theory}

Stress theory is used to describe how stress generated from a parental divorce works as a 'push' factor to prompt youth to enter adult roles such as marriage, cohabitation, premarital sex and parenthood, at an earlier age. When used as an explanatory pattern of the intergenerational transmission of divorce, stress theory focuses "on family events and their consequences for family organization and dynamics" (McLanahan and Bumpass, 1988: 134). The underlying assumption is that an event such as a divorce leads to instability in the family system. This instability drives children to leave their family of origin at a younger age and therefore take on earlier adult roles. Stress theory predicts that parental divorce may encourage children to leave home, marry prematurely and become sexually active earlier than children from intact families (McLanahan and Bumpass, 1988).

Several studies have demonstrated that children with divorced parents are more likely to take on adult roles earlier, such as early marriage (see Diekmann and Engelhardt, 1995 for Germany; Glenn and Kramer, 1987 and McLanahan and Bumpass, 1988 for the US). An early marriage may afford the chance to escape from an unpleasant home situation or provide an emotional replacement that is lacking in the parental home (Glenn and Kramer, 1987).

Others have found that children of 'divorced' parents are more likely to enter into cohabiting unions than their peers from intact families. Cherlin et al. (1995) found that children of divorced families in the UK had a higher tendency to opt for premarital cohabitation. Le Bourdais and Marcil-Gratton (1998) found that children of 'divorced' parents in Canada were two times more likely to experience cohabitation before the age of 25 but less likely to marry in their younger years than those from intact families. This differs from the previous studies mentioned above (e.g., McLanahan and Bumpass), which found that children who experienced parental divorce tend to marry early. These studies revealed a 


\section{The Consequences of Parental Divorce on the Life Course Outcomes \\ of Canadian Children}

difference between the US and Canadian contexts with respect to early marriage of children of divorcees, which is likely to be related to contextual factors such as the different cultural and legal structures. If we base our assumptions on the majority of research to this point, stress theory would lead us to predict that there will be more early marriages before the age of 25 . Our first hypothesis is based on the assumption that parental divorce is a 'push factor' to leave home and/or to create one's own stable family situation.

H 1: Parental divorce will increase the risk of early marriage for children of divorcees before the age of 25 .

Since stress theory views parental divorce as a 'push factor' for children to take on earlier adult roles, the aspect of premarital sex and birth is also relevant. We have chosen to examine out of wedlock births, as opposed to premarital sexual behaviour for several reasons. First, norms regarding sexual behaviour have changed to the extent that a pre-marital sexual experience is neither 'shocking' nor labelled as a 'deviant' behaviour for many young individuals. It therefore seems more efficient to examine the impact of parental divorce on premarital birth. Second, our data does not provide adequate information regarding sexual behaviour. Not all respondents have experienced early sexual behaviour or can recall the exact timing, and unfortunately, some might not be prepared to give an honest statement. Finally, in contrast with early sexual experiences, a birth is a life-changing event. It has the potential to lead to parental conflict and 'push' children to leave the parental home to start their own family life, with independent 'love and security'.

McLanahan and Bumpass (1988) found that women who grew up in a one-parent family were more likely to have premarital births and become parents earlier than those who grew up in intact families. Cherlin et al. (1995) also discovered a strong effect of parental divorce on premarital birth for men and women, attributing it to several factors: "obvious sexual activity of divorced parents may stimulate nonmarital sexual activity in their children. (...). Adolescents' early sexual activity could constitute rebellious or acting out behaviour begun in reaction to an unwelcome parental divorce" (Cherlin et al., 1995: 313). ${ }^{2}$ Of course, even in intact families, we contend that early sexual behaviour could also be considered as a rebellious act. Axinn and Thornton (1996) likewise found a strong relationship between mother's divorce and premarital sexual experience, linking the behaviour of offspring to their mothers. Le Bourdais and Marcil-Gratton (1998) showed that girls who experienced parental divorce were more likely to give birth before the age of 20 irrespective of their marital situation.

Based on these previous findings, we contend that the premises of stress theory will also hold in relation to early births. In other words, parental divorce is a 'push 
Martin, Valerie, Melinda Mills and Céline LeBourdais

factor' to become an adult faster, which will result in earlier sexual experiences and younger premarital births for children of divorcees, leading to the second hypothesis.

H 2: $\quad$ Young women who have experienced the divorce of their parents will have a higher risk of having a premarital birth in comparison to those who come from intact families.

Only young women are examined, due to the lower quality of fertility data for men and to the fact that the latter might not always be aware of an unplanned nonmarital birth.

\section{Socialization theory}

Another way to understand the impact of parental divorce is through socialisation theory, which postulates different assumptions from those of stress theory. Socialisation theory argues that the effects of marital disruption arise from changes in the family structure and transmission of attitudes, values and roles rather than the conditions associated with life in a single-parent family. The main assumption is that attitudes towards divorce, family formation and roles are transferred from one generation to the next. Here, it is important to return to the definitions of family types and to differentiate among one-parent families. One-parent families may be the result of the death of one partner or caused by family disruption ${ }^{3}$ Children's socialisation concerning attitudes towards divorce might differ strongly between these two family types. Socialisation theory generally deals with the question of how parents transfer attitudes regarding different family behaviour to their children or, in other words, of 'attitude role taking' concerning family values (Diekmann und Engelhardt, 1995).

Axinn and Thornton (1996: 69) argue that 'parents' attitudes toward premarital sex, cohabitation, marriage, childbearing and divorce are likely to have a strong influence on their children's attitudes." Firstly, attitudes could be internalised passively or actively by support or control. Secondly, parents and children could share common values and attitudes because of their similar social position. A common social position could include religious behaviour and other cognitive systems of values and norms.

Other researchers have focussed on role models. McLanahan and Bumpass (1988) insist on the importance of role models and parental supervision for children and young adults. Parental divorce, they argue, can undermine parental authority and social control, with single mothers generally being less 'disciplinarian'. Their findings show a higher probability of divorce for daughters who grew up only with 


\section{The Consequences of Parental Divorce on the Life Course Outcomes \\ of Canadian Children}

their mother compared to those who grew up with both parents. In the absence of a father, they contend: "Daughters of single mothers learn that women are capable of managing a family alone" (McLanahan and Bumpass, 1988: 133).

Glenn and Kramer (1987) also analysed the role-model effect by considering five explanations: 1) absence of modelling of spousal roles; 2) inadequate social control; 3) inappropriate modelling of spouse; 4) greater willingness to resort to divorce; and, 5) lower commitment to marriage. For the purpose of our paper we discuss points 1,3 and 5 in more detail. First, in the absence of modelling of spousal roles, children growing up with a lone parent lack the possibility to learn how a relationship works and how partners act together appropriately, which is pertinent to both children from divorced parents and those who experienced the death of one parent (see McLanahan and Bumpass, 1988). The third related explanation assumes that children experiencing a failed parental marriage do not receive positive or have inappropriate role models concerning relationships and that their parents are unable to teach them the basics of a 'good marriage'. However, it is problematic to find an indicator for a 'good marriage'. Furthermore, even if parents do not divorce, their marriage could be inadequate in many ways; they could face the existence of affairs, financial problems, etc.

Assumption five deals with the fact that children of divorced parents are less likely to make such a long-term commitment as marriage. They tend to expect that their marriage could fail as well, which serves as a self-fulfilling prophecy (Glenn and Kramer, 1987). Children see their parents solve relationship conflicts by ending the relationship; conversely, they may learn how to handle problems without resorting to divorce and be aware of the normal ups and downs of such a longterm commitment.

The role-model effect of divorced parents has potential consequences on the union behavior of children and is likely related to the increase of couples living together without a legal marriage in Canada. In fact, $\mathrm{Wu}$ (2000) recently argued that common-law partnerships are becoming an alternative to marriage, which occurs to an even higher extent in Quebec than elsewhere in Canada (Pollard and Wu, 1998). Le Bourdais and Marcil-Gratton (1998) showed that children of divorced parents tend to cohabit as opposed to entering a marriage. There are also divergent motivations for cohabitation as opposed to marriage (see Mills, 2004). Mills and Blossfeld (2005) argue that cohabitation is a 'rational' reply to uncertainty such as that which is produced by parental divorce, as it allows youth to make a nonbinding decision for the future. Some couples may cohabit because they are unsure of the stability of the relationship or their own future, or consider it as a 'trial marriage'. Others may consider marriage as merely a legal status, but share the same values as married couples such as trust, commitment, and mutual responsibility. 
For children experiencing a parental divorce who do not want to remain single, cohabitation could serve as a sort of flexible 'middle ground': no legal obligations and constraints on the one hand, but a 'mutual agreement' for a 'quasi long-term commitment' without obligations and constraints on the other. This idea is formulated in the following hypothesis.

H 3: Children coming from divorced parents will have a higher rate of cohabitation than marriage compared to children from intact families.

Although children of divorced parents might have difficulties with a long-term commitment such as marriage, a more interesting question is what will happen to their marriages if they indeed enter such a relationship. There are two central interpretations of the impact of parental divorce on children's risk of divorce. First, their attitudes towards divorce might differ from those of children from intact families. Axinn and Thornton (1996) discovered a strong influence of maternal divorce on children's acceptance of divorce, concluding that children react directly to the experience of their parent's marital dissolution. Amato (1996) likewise argued that children from disrupted families are more at risk of divorce because they have liberal attitudes towards divorce. In their childhood or adolescence, these children saw that divorce can be a solution for an unhappy marriage.

Second, their trust in and ability to make such a long term commitment might be weaker compared to children of intact families. Amato (1996) suggested that children growing up with one parent lack certain interpersonal behaviour skills and emotional stability, which may result in lack of trust or high jealousy that translates into lower commitment. This leads to the following hypothesis:

H 4: Children of divorced parents are more likely to experience their own marital dissolution compared to respondents coming from intact families.

A further 'control' variable of children of deceased parents will be added in the analysis to separate the effects of this group from children of divorced parents.

Finally, it is assumed that individuals growing up in a high divorce population are less likely to experience a negative impact of parental divorce due to the wider acceptance of divorce (Glenn and Kramer, 1987; Wolfinger, 1999). Consequently, they should face a lower risk of separation than those living in a lower divorce environment; their behaviour, in terms of forming a union and giving birth outside of marriage, should be less closely linked to parental divorce. In other words, we would expect parental divorce to exert a smaller impact on the life course outcomes of children in Quebec, where the divorce rate is higher, than elsewhere in Canada. Though not formulated as a separate hypothesis, this expectation will 


\section{The Consequences of Parental Divorce on the Life Course Outcomes \\ of Canadian Children}

be tested across models by the introduction of interaction term (see the section on data and methods below).

\section{Economic deprivation theory}

A final theoretical approach is the study of the influence of economic deprivation in childhood caused by parental divorce. The main emphasis of this theory is the assumption that single parents have less time and money for their children. In a situation of economic deprivation, the child might adopt adult roles earlier than usual to contribute time and money to the family household (McLanahan and Bumpass, 1988). If this is the case, many children are disturbed in their normal development (e.g., hobbies, education). The findings to this point, however, remain inconclusive (Amato, 1993).

Amato (1996) argues that single mothers often experience economic hardship because of the divorce, which translates into the inability to provide additional resources such as educational games, computers, books or private lessons to their children (Amato, 1996; see also Diekmann and Engelhard, 1995). Amato's (1996) arguments, however, could not be verified, as no evidence of a strong association between socio-economic status and divorce behaviour was found. Similarly, McLanahan and Bumpass (1988) and Diekmann and Engelhardt (1995) could not find enough valid evidence to prove that the effect of parental divorce operates through the socio-economic deprivation. They argued that for children growing up with one parent because of death, the effects of economic deprivation should be similar.

The inconclusive findings may be partially related to the difficulties in studying economic deprivation. First, in a retrospective data set, such as the one used in this study, respondents may be unable to accurately recall their economic situation during childhood. Second, low socio-economic status in general needs to be distinguished from whether it is a consequence of a divorce. Low socio-economic status per se may lead to marital conflict and increase the possibility of a divorce or may be exogenous to the partnership process. Divorce may also be a very expensive experience (see Kopp and Hill, 1995; Amato, 1996; Cherlin, 1992). To examine this issue successfully, panel data that can ascertain whether the socioeconomic status changed over time either during childhood (e.g., caused by divorce, unemployment) or during the offspring's adult life would be required. However, it is possible to use the educational status of respondents (i.e., offspring) as an indicator or proxy for financial well-being. The expectation is that the risk of divorce increases as educational attainment decreases. Consequently, the level of educational attainment is included in the analysis as a control variable. 
Martin, Valerie, Melinda Mills and Céline LeBourdais

One assumption is that people with lower educational attainment may not have the same abilities to communicate and to solve marital problems than people with higher educational attainment. Yet, Le Bourdais and Marcil-Gratton (1998) present support for an alternative hypothesis by showing that the likelihood to end a marriage by separation increases with each additional year in school. They conclude that the more educated a woman is, the higher the likelihood that she will be independent, which is demonstrated by better chances in the labour market and potential for more resources and power. This increases the possibility for women to escape from an unhappy marriage without the risk of poverty or unemployment. These two seemingly contradictory assumptions suggest a potential U-shaped relationship, with those with low and high levels of education more likely to divorce.

\section{Data and Methods}

The empirical analysis is based on data from the 1995 Canadian General Social Survey (GSS) on the family. The initial response rate was 90.4 per cent including 11,985 responding households, which was later reduced to 10,749 (80.7 per cent) usable respondents aged 15 years and older. People living in the Yukon and Northwest Territories $^{5}$ and full-time residents of institutions were excluded from the survey (Statistics Canada, 1997a). The GSS is a retrospective survey. Therefore, some respondents may not recall exactly when their parents divorced or other childhood aspects.

For the purpose of the analysis, we considered only respondents born in an 'intact' family and thus excluded those born in step-families. 47 respondents were further excluded due to missing data or inconsistencies in their conjugal histories (for example, some respondents provided a date of divorce but not of marriage). The final sample size thus consists of 8,446 respondents, males and females, for the analysis of union formation. In the study of premarital birth, men are excluded from the analysis, and the sample comprises 4,834 women. Finally, the analysis of marital disruption is based on 1,260 ever-married male and female respondents.

The empirical analyses consist of a series of event history models (see Blossfeld and Rohwer, 2002). Event history analysis, which combines life table analysis and regression methods, is a useful technique to study the timing of an event in relation to covariates, which may vary over time, and to take into account individuals with incomplete histories, that is, individuals who had not yet experienced the event under consideration by the time of the survey (i.e., right-censored). Events in this analysis include cohabitation, marriage, marital separation, and birth of first child. The regression models examine the effects of covariates on the respective dependent variable, that is, on the 'hazard' rate of experiencing a transition from 
one state to another, such as the transition from the state of marriage to divorce, conditional to the fact that the individuals have not yet experienced the transition and are still under observation. When examining the risk of individuals to enter conjugal life through cohabitation or marriage, these transitions are treated as two competing events; in other words, from the moment an individual experiences one event (for example, cohabitation), he/she is no longer at risk of experiencing the other (for example, marriage), and he/she is thus excluded from the risk set from this moment on.

Several covariates are included in the analysis. The central variable to our study indicates whether the respondents' parents were either divorced or separated before they reached the age of 17 . Respondents' educational attainment is coded into four categories: 1) less than high school attainment; 2) high school diploma; 3 ) post-secondary education; and 4) university degree. The information on religious behaviour allows us to distinguish among respondents who are: 1) Catholics, 2) Protestants, 3) from another religion (e.g. Islamic or Jewish), or 4) who declare no religion. Regional differences were taken into account by comparing Quebec respondents with those living elsewhere in Canada. To test for the existence of a differential impact of parental divorce on the life course of children living in regions characterised by different levels of divorce, we created an interaction term that combines parental divorce and region of residence.

A Cox (1972) model is used to examine the transition to early marriage, premarital birth, entry into marriage or cohabitation as a first union, and divorce (for a presentation of the model, see Cox, 1972; Blossfeld and Rohwer, 2002).

\section{Results}

The results are now discussed in relation to the four hypotheses outlined previously. Table 1 shows the results of the final model coefficients for entry into early marriage, type of first union formation and premarital birth. The impact of parental divorce on respondent's own levels of divorce is shown in Table 2.

\section{The Impact of Parental Divorce on Early Entry into Marriage}

Recall that the aim of the first hypothesis was to test whether children of divorcees had a higher transition rate to marriage at an early age (i.e., before the age of 25), compared with those from intact families. Stress theory predicts that parental divorce is a 'push factor' for children to take on adult roles earlier, such as marriage. The results in the first column of Table 1 show that although children of 
divorcees are 1.11 times more likely to enter marriage at an earlier age, the effect of parental divorce is not significant, once controlling for the other covariates. There are, however, several other interesting results in this model.

The findings indicate that as the level of educational attainment increases, the likelihood to marry at an early age decreases. For example, those with a university degree have a 33 per cent lower likelihood to wed in comparison to those who obtained a high school diploma. This finding is logical considering the time constraints and financial circumstances of students.

Another significant difference is the unique demographic patterns observed in Quebec in comparison to the rest of Canada. Individuals from Quebec are much less likely to marry at an early age compared to individuals living elsewhere in Canada. This result reflects previous research, which describes how the 'quiet revolution' in Quebec resulted in significant changes in life course behaviour, such as a rejection of marriage in favour of cohabitation (see Wu, 2000; Mills, 2000; Le Bourdais and Juby, 2001). The lower propensity of Quebeckers to marry does not, however, appear to be related to a lower impact of parental divorce on children's early entry into marriage in Quebec, as was hypothesized. The introduction of an interaction term between parental divorce and region does not significantly improve the fit of the model and the interaction term is not statistically significant (see the lower panel of Table 1).

Religious affiliation is another important predictor of entering into marriage at a younger age. Catholics and Protestants have respectively a 22 and 42 per cent higher rate of entry into early marriage compared to those declaring no religion. The lower likelihood of entry into early marriage for Catholics in comparison to Protestants is likely related to the more stringent view of divorce. This in turn, produces a relatively more calculated decision for youth when making this binding life course transition.

\section{The Impact of Parental Divorce on Type of First Partnership}

Parental divorce is expected to not only influence the timing of entry into first partnerships, but also the type of first union that the children of divorcees form. The third hypothesis, based on socialisation theory, predicts that children coming from divorced parents are more likely to cohabit rather than marry. The assumption is that the experience of parental divorce may lead to negative feelings concerning marriage, thus positioning common-law partnerships as a more favourable option. As discussed in the introduction, Quebec has had consistently high cohabitation and divorce rates, which sets it apart from the rest of Canada. We therefore also anticipate differences in this respect. 
The Consequences of Parental Divorce on the Life Course Outcomes

of Canadian Children

Table 1

Impact of Various Characteristics on the Risk of Experiencing an Early Marriage, of forming a Marriage or Common Law Union, and of having a Premarital Birth among Individuals Born in an Intact Family, Canada

a) Basic Model $\quad$ Risk Ratio $(\exp (\beta))^{b}$

\section{a) Basic Model}

\section{Type of First Union}

\begin{tabular}{|c|c|c|c|c|}
\hline Covariates $^{\mathrm{a}}$ & $\underset{<25}{\text { Early Marriage }}$ & Marriage & Cohabitation & $\begin{array}{c}\text { Premarital } \\
\text { Birth }^{\mathrm{c}}\end{array}$ \\
\hline \multicolumn{5}{|l|}{ Parents divorced <age 17} \\
\hline Yes & 1.11 & 1.13 & $2.96 * * *$ & $1.49 *$ \\
\hline No & 1 & 1 & 1 & 1 \\
\hline \multicolumn{5}{|l|}{ Educational Level } \\
\hline$<$ High School Education & $1.16^{* * *}$ & 1.03 & 1.06 & $1.23 * *$ \\
\hline (High School) & 1 & 1 & 1 & 1 \\
\hline Post Secondary Education & $0.83 * * *$ & $0.85^{* * *}$ & $2.01 * * *$ & 1.18 \\
\hline University Degree & $0.67 * * *$ & $0.76^{* * * *}$ & $1.21 * * *$ & 0.90 \\
\hline \multicolumn{5}{|l|}{ Region } \\
\hline Quebec & $0.81 * * *$ & $0.78 * * *$ & $1.77 * * *$ & $0.61 * * *$ \\
\hline (Rest of Canada) & 1 & 1 & 1 & 1 \\
\hline \multicolumn{5}{|l|}{ Religion } \\
\hline (No Religion) & 1 & 1 & 1 & 1 \\
\hline Catholic & $1.22 * * *$ & $1.23 * * *$ & $0.58 * * *$ & 0.91 \\
\hline Protestant & $1.42 * * *$ & $1.33 * * *$ & $0.43 * * *$ & 0.91 \\
\hline Other Religion & 0.90 & 1.00 & $0.21 * * *$ & 0.77 \\
\hline Log-likelihood null model & -38525.94 & -67537.64 & -67537.64 & -6677.73 \\
\hline Log-likelihood complete model & -38354.31 & -67226.80 & -67226.80 & -6649.28 \\
\hline
\end{tabular}

\begin{tabular}{lcccc}
\hline $\begin{array}{l}\text { b) Model with Interaction Effect } \\
\text { Parents divorced <age 17 } \\
\quad \text { Yes }\end{array}$ & 1.08 & 1.05 & $2.33^{* * * *}$ & 1.22 \\
$\begin{array}{l}\text { Region } \\
\text { Quebec }\end{array}$ & $0.81^{* * *}$ & $0.78^{* * *}$ & $1.73^{* * *}$ & $0.60^{* * *}$ \\
Quebec* Parents Divorced & 1.09 & 1.35 & $1.69 * * *$ & 2.08 \\
& & & & \\
Log-likelihood final model & -38354.26 & -67223.95 & -67223.95 & -6648.21 \\
N & 8,446 & 8,446 & 8,446 & 4,834 \\
\hline
\end{tabular}

${ }^{\mathrm{a}}$ Reference category in parentheses.

${ }^{\mathrm{b}}$ Significance levels (2-tailed tests): $* * * \mathrm{p}<=0.01, * * \mathrm{p}<0.05, \mathrm{p}<=0.10$.

${ }^{\mathrm{c}}$ Includes only women; ${ }^{\mathrm{d}}$ After controlling for educational level and religion.

Source: Statistics Canada: General Social Survey 1995, Cycle 10, The Family. 
Turning to the results of the second and third columns of Table 1, we see that the overall likelihood to enter both marriage and cohabitation is higher for children of divorced parents than for those from intact families, but statistically significant only for the latter. Children of divorced parents are nearly three times more likely to enter cohabiting unions than those from intact families, thus providing support for the third hypothesis.

The findings likewise demonstrate an interesting difference between level of education and the type of first union formation. Highly educated individuals are more likely to cohabit than those with a high school diploma; by contrast, they are less likely to choose marriage to start their conjugal life. As expected, individuals from Quebec are significantly less likely to marry and more likely to cohabit than those from the rest of Canada: they have a 22 per cent lower chance to start their conjugal life through marriage, but a 77 per cent higher chance to do so through cohabitation. The introduction of an interaction term to the model reveals interesting findings that partly run counter to our expectations (lower panel of Table 1). Quebeckers who experienced the divorce of their parents differ from those who grew up in an intact family, and the difference separating these two groups is larger than that observed among respondents living outside of Quebec. Hence, children of divorce living in Quebec have a significantly higher likelihood to enter both marriage and cohabitation than those raised in an intact family. ${ }^{6}$ In other words, although divorce is more frequent in Quebec, its impact on children's outcomes remains stronger than elsewhere in Canada, thus infirming our hypothesis of the reduced effect of parental separation in a high divorce population.

Finally, having a Catholic or Protestant religious affiliation has a highly significant and positive influence on the likelihood to marry and negatively affects entry into a cohabiting union. The highly significant and negative impact on the transition to cohabitation for all the religious groups indicates that even in more recent years, common-law partnerships remain a relatively selective form of partnership. The fact that Catholics are slightly more likely to cohabit (and less likely to marry) than Protestants is again in line with the previous discussion about the restrictions of divorce for Catholics, which can be avoided by entering a cohabiting union.

\section{The Impact of Parental Divorce on Premarital Birth}

The second hypothesis maintained that parental divorce would lead to a higher likelihood of premarital births, partially attributed to earlier sexual behaviour. The results in the last column of Table 1 provide clear support for this hypothesis, with women from divorced parents having a significantly higher likelihood of having an out of wedlock birth. Lower educational attainment increases the likelihood of 
a premarital birth by 23 per cent. This could be related to the fact that women with lower educational attainment start working earlier and have more financial stability to start a family than their counterparts who remain students for a longer period.

The inter-region differences are again apparent with a significantly lower propensity to have a premarital birth in Quebec as opposed to elsewhere in Canada. Here, it is important to note that women in this province have a higher likelihood to engage in cohabiting as opposed to marital unions, which would mean that births within these unions would fall into the group of 'premarital' or 'out of wedlock' births. It is therefore even more interesting to have such a highly negative effect, suggesting not only a rejection of marriage, but also of parenthood. The introduction of an interaction term in the equation did not reveal any significant difference across regions in the impact of parental divorce on the propensity of women to have children outside of marriage (see the lower panel of Table 1).

In accordance with the second hypothesis, we can therefore confirm that parental divorce appears to be a clear 'push factor' for girls to take on early adult roles, in this case entry into parenthood, in comparison with girls from intact families. This finding may, in part, be related to the previous discussion of earlier sexual activity, due to push factors out of the parental household, or lack of supervision or of a disciplinary parental figure.

\section{The Impact of Parental divorce on their Children's Marital Dissolution}

The fourth hypothesis asks: Is it really the case that children of divorced parents are more likely to divorce themselves? In other words, in the event that they marry, will children of divorce 'protect' their marriage in order to avoid the negative effects of divorce experienced by their own parents? Or, do they see divorce as a viable option? Socialisation theory predicts that children coming from divorced parents are strongly exposed to the risk of divorce. In order to separate the more general impact of coming from a one-parent family from that of a divorced one, we introduced a dummy variable into the analysis to identify children who experienced the death of one parent, with the aim of isolating the socialisation effect of role-modelling.

Table 2 provides support for hypothesis four and socialisation theory, showing that children coming from divorced parents are approximately 1.5 times more likely to divorce themselves in comparison to those raised in intact families and those who experienced the death of one parent. It appears that children of divorced parents may have higher levels of divorce due to the fact that they have experienced 
Martin, Valerie, Melinda Mills and Céline LeBourdais

divorce as an acceptable solution to leave an undesirable marriage. As described within the socialisation argument, it is likely related to the lack of role modelling of alternative ways to solve problems in a partnership, but not to the absence of a parental figure per se, as the death of one's parent does not appear to be associated with a higher risk of marital disruption. Furthermore, parents would not morally judge these children when obtaining a divorce because they had a similar experience. Finally, these children of divorcees may not have trust in the longterm commitment of marriage.

Concerning the covariates, we see that educational attainment is significantly linked to the transition rate to divorce. The likelihood to divorce increases by nearly 40 per cent for respondents who had attended at least some post secondary education, compared to the reference category of those who had obtained a high school diploma. Respondents with a university degree also have a 17 per cent higher likelihood to divorce than those who had just completed a high school degree. This result runs counter to the expectation of economic deprivation theory, namely that the risk of divorce should increase as the level of educational attainment decreases. However, it does confirm the findings of another Canadian study (Le Bourdais and Marcil-Gratton, 1998) that argued that highly educated individuals, and particularly women, likely face better opportunities on the labour market, have higher levels of autonomy, and the resources needed to afford the high financial costs of divorce. The influence of religion on the likelihood to divorce is negative for both Catholics and Protestants, compared to the reference category of respondents reporting no religion. These findings show once more that religious affiliation serves as a barrier for divorce.

The risk of marital disruption does not appear to significantly differ across regions, nor does the impact of parental separation on children's union seem to vary between regions (see the lower panel of Table 2). The assumption that young people growing up in a high divorce population are less likely to be affected in their marriage by parental divorce, due to a higher acceptance of divorce in such society, is thus not verified.

\section{Conclusion and Discussion}

The goal of this paper was to examine the impact of parental divorce on certain life course events of children with the aid of the theory of the intergenerational transmission of behaviour. Using the three notions of stress, socialisation and economic deprivation, four central hypotheses were tested to examine the consequences of divorce for children's union formation and dissolution, and fertility. Socialisation theory offered the most plausible and powerful explanation, 
The Consequences of Parental Divorce on the Life Course Outcomes

of Canadian Children

Table 2

Impact of Various Characteristics on the Risk of Experiencing a Marital Separation or Divorce among Married Individuals Born in an Intact Family, Canada

\begin{tabular}{|c|c|}
\hline \multicolumn{2}{|c|}{ Risk Ratio $(\exp (B))^{b}$} \\
\hline \multicolumn{2}{|l|}{ Covariates $^{\mathrm{a}}$} \\
\hline \multicolumn{2}{|l|}{ Parents divorced <age 17} \\
\hline Yes & $1.49^{* *}$ \\
\hline No & 1 \\
\hline \multicolumn{2}{|l|}{ Educational Level } \\
\hline$<$ High School Education & 0.99 \\
\hline (High School) & 1 \\
\hline Post Secondary Education & $1.38 * * *$ \\
\hline University Degree & $1.17 * *$ \\
\hline \multicolumn{2}{|l|}{ Region } \\
\hline Quebec & 0.99 \\
\hline (Rest of Canada) & 1 \\
\hline \multicolumn{2}{|l|}{ Religion } \\
\hline (No Religion) & 1 \\
\hline Catholic & $0.77 * * *$ \\
\hline Protestant & $0.77 * * *$ \\
\hline Other Religion & 0.92 \\
\hline Log-likelihood null model & -7742.00 \\
\hline Log-likelihood complete model & -7724.32 \\
\hline \multicolumn{2}{|c|}{ b) Model with Interaction Effect ${ }^{c}$} \\
\hline \multicolumn{2}{|l|}{ Parents divorced <age 17} \\
\hline Yes & $1.45^{*}$ \\
\hline \multicolumn{2}{|l|}{ Region } \\
\hline Quebec & 0.99 \\
\hline Quebec* Parents Divorced & 1.05 \\
\hline Log-likelihood final model & -7724.32 \\
\hline $\mathbf{N}$ & 1.260 \\
\hline
\end{tabular}

${ }^{\mathrm{a}}$ Reference category in parentheses.

${ }^{\mathrm{b}}$ Significance levels (2-tailed tests): $* * * \mathrm{p}<=0.01, * * \mathrm{p}<0.05, \mathrm{p}<=0.10$.

${ }^{c}$ After controlling for educational level, religion and death of parent.

Source: Statistics Canada: General Social Survey 1995, Cycle 10, The Family. 
with children from divorced parents appearing to take on the attitudes towards marriage and divorce of their parents. Significantly higher levels of entry into cohabitation, as opposed to marriage, and higher levels of divorce were found among children of divorce, compared to children from intact families, thus demonstrating this socialisation effect. It seems that these attitudes towards family formation, divorce and roles are indeed transferred from one generation to the next.

The hypotheses based on stress theory showed mixed findings. It appeared that although children from divorced parents did have a higher likelihood to enter both marital and cohabiting unions, compared to children from intact families, they did not enter marital unions at significantly earlier age. However, the significantly higher likelihood of girls from divorced families to have a premarital birth does provide support for the 'push' or 'stress' factor that stress theory predicts. The weakest support was found for the economic deprivation theory, where the reverse statistical association to that expected was found between children's educational attainment and marital disruption. We contend, however, that this finding may in part be linked to the operationalization of economic deprivation in our study, which was approached through the level of education attained at the time of the survey rather than through direct measures of economic status during childhood.

The analysis revealed the divergent demographic behaviour of persons in Quebec compared to those living elsewhere in Canada. Quebeckers were less likely to choose marriage and more likely to opt for cohabitation as a way to start their conjugal life; they showed a lower propensity to have a premarital birth but no difference in their likelihood to experience marital disruption. The higher rate of divorce observed in Quebec did not appear to reduce the impact of parental separation on children's outcomes, as expected. On one hand, and contrary to our hypothesis, the experience of parental divorce was shown to more steeply increase the likelihood to both marry and cohabit in Quebec than elsewhere in Canada. On the other hand, no difference across regions was found in the effect of parental divorce on children's risk of having a premarital birth and marital separation.

The results reflect those of previous studies in Canada, but show that the patterns observed within Canada and in the U.S. context somewhat differ. This is apparent in the lack of statistically significant results found in the analysis of earlier age at entry into marriage or in the lack of support noted for the economic deprivation theory. This difference is likely related to a somewhat stronger social safety net within the Canadian welfare regime (e.g., duration and level of social assistance, health care), and alimony system. In other words, children of divorce may not need to enter marriage in order to gain economic security or experience as large of a negative impact of the economic consequences of divorce as children in the U.S. 
Although this study provides several useful findings in relation to the life course outcomes of children of divorce, future research would benefit from the use of panel data to study the longer-term consequences of parental divorce. In addition, this kind of data would enable to more accurately capture the changing economic situation during childhood. Second, these quantitative findings could be supported by more qualitative studies that examine the psychological effects of a parental divorce on children, and not only the life course events that they experience. Third, the original theory of the intergenerational transmission of divorce focuses only on parental divorce and its outcomes and not on common-law separations. The growth of consensual unions and more diverse family structures in Canada and elsewhere demands a revision of the theory that examines only the intergenerational transmission of divorce. Future research on the impact of common-law separations on children would be a further step, now that commonlaw unions are becoming a common environment in which to start and raise a family in Canada and especially in Quebec. This would be particularly interesting considering the differences that exist in juridical barriers to separation, in legal recognition of common-law unions according to duration, understanding of commitment, and so forth. Fourth, with the General Social Survey on family that interviewed almost 25,000 respondents in 2001, this study could be replicated to examine changes over time, but also undertake more refined data analyses. A final future area of research would be the examination of the second generation of divorced families, including the role of stepfamilies in affecting children's life courses when they reach adulthood. It would be interesting to see if these higher rank divorces have a different or more detrimental impact on children born within these unions.

\section{Acknowledgements:}

An earlier version of this paper, which is based on Valerie Martin's (2003) master's thesis, was presented in the session Parents and Children in Canada of the 2004 Annual Meeting of the Canadian Population Society held in Winnipeg. The authors are grateful to the anonymous reviewers for their helpful comments.

\section{End Notes:}

1. See Pope and Mueller (1976) and Mueller and Pope (1977) who introduced the notion of intergenerational transmission of marital instability in the late 1970s.

2. For a psychological view, see Stevens-Long and Cobb (1983). 
3. One-parent families can also result from a birth outside a union. These families are excluded here since we focus solely on children born in twoparent families.

4. Lewis and Spanier attempted to provide some indicators for the quality of a marriage: "good judgement, adequate communication, a high level of marital happiness, integration, and a high degree of satisfaction with the relationship" (Lewis and Spanier, 1979, in Kopp and Hill, 1995: 211).

5. For further information, see Statistics Canada (1997). These territories were excluded for several reasons, mainly due to the fact that their population is difficult to reach with the computer assisted telephoning data collection methods used for this survey. This population is not large, and consists largely of Natives, many of whom do not have a telephone. Considering the different patterns of union formation, dissolution, and other life course patterns in these northern territories, it would be important population to examine in future research.

6. Once an interaction term is introduced in the equation, the parental divorce and region coefficients can no longer be interpreted separately. By combining the appropriate coefficients, we obtain the following risk ratios across regions for children who experienced parental divorce as compared to those who did not:

\begin{tabular}{llcc}
\hline & & Marriage & Cohabitation \\
\hline \multirow{3}{*}{ Rest of Canada } & Parents & & \\
& not divorced $<17$ & 1 & 1 \\
& Parents divorced $<17$ & 1.05 & 2.33 \\
& Parents & & \\
Quebec & not divorced $<17$ & 0.78 & 1.73 \\
& Parents divorced $<17$ & 1.11 & 6.81 \\
\hline
\end{tabular}


The Consequences of Parental Divorce on the Life Course Outcomes

of Canadian Children

\section{References:}

Amato, P.R. 1993. "Children's Adjustment to Divorce: Theories, Hypotheses, and Empirical Support." Journal of Marriage and the Family, 55: 23-38.

Amato, P.R. 1996. "Explaining the intergenerational Transmission of Divorce." Journal of Marriage and the Family, 58: 628-640.

Axinn, W.G. \& Thornton, V. 1996. "The Influence of Parents Marital Dissolution on Children's Attitudes Toward Family Formation.” Demography, 33: 6681.

Blossfeld, H.-P. \& Rohwer, G. 2002. Event History Analysis. Mahwah (N. J.): Lawrence Erlbaum Associates, Publishers. Second Edition.

Bumpass, L.L., Raley, R.K. \& Sweet, J.A. 1995. “The Changing Character of Stepfamilies - Implications of Cohabitation and Nonmarital Childbearing." Demography, 32 (3): 425-436.

Cherlin. A.J. 1992. Marriage, Divorce, Remarriage. Social Trends in the United States. Cambridge (Ma.): Harvard University Press.

Cherlin, A.J., Kiernan, K.E. \& Chase Lansdale, P.L. 1995. "Parental Divorce in Childhood and Demographic Outcomes in Young Adulthood." Demography, 32: 299-318.

Cox, D. 1972. "Regression models and life-tables." Journal of the Royal Statistical Society. Series B, 34: 187-202.

Diekmann, A. \& Engelhardt, H. (1995). "Die soziale Vererbung des Scheidungsrisikos. Eine empirische Untersuchung der Transmissionshypothese.” Zeitschrift für Soziologie, 24 (3): 275-295.

Glenn, N.D. \& Kramer, K.B. 1987. "The Marriages and Divorces of the Children of Divorce." Journal of Marriage and the Family, 49: 811-825.

Kopp, J. \& Hill, P. B. 1995. Familiensoziologie. Grundlagen und theoretische Perspektiven. Stuttgart: Teubner. 
Martin, Valerie, Melinda Mills and Céline LeBourdais

Le Bourdais, C. \& Juby, H. 2001. "The Impact of Cohabitation on the Family Life Course in Contemporary North America : Insights from Across the Border". In A. Booth and A.C. Crouter (eds), Just Living together: Implications of Cohabitation for Children, Families, and Social Policy. Mahwah (N.J.): Lawrence Erlbaum Associates, 107-118.

Le Bourdais, C. \& Marcil-Gratton, N. 1998. "The Impact of Family Disruption on Outcomes in Young Adulthood”. In M. Corak (ed.), Labour Markets, Social Institutions, and the Future of Canada's Children. Ottawa: Statistics Canada and Human Resources Development, 91-105.

Le Bourdais, C., Neill, G. \& Marcil-Gratton, N. 2000. "L'effet du type d'union sur la stabilité des familles dites 'intactes"'. Recherches sociographiques, XLI: 53-74.

Martin, V. 2003. What Is the Impact of Parental Divorce in Canada? Diplomarbeit Fakultät für Soziologie, Universität Bielefeld (Germany).

McLanahan, S. \& Bumpass, L.L. 1988. "Intergenerational Consequences of Family Disruption.” American Journal of Sociology. 94: 130-152.

Mills, M. 2000. The Transformation of Partnerships. Amsterdam: Thela Thesis.

Mills, M. 2004. "Stability and Change: The Structuration of Partnership Histories in Canada, the Netherlands and the Russian Federation." European Journal of Population, 20: 141-175.

Mills, M. and H.-P. Blossfeld. 2005. "Globalization, Uncertainty and the Early Life Course: A Theoretical Framework,” In H.-P. Blossfeld et al. (eds), Globalization, Uncertainty and Youth in Society. London/New York: Routledge, 1-24.

Mueller, C.W. \& Pope, H. 1977. "Marital Instability: A Study of its Transmission Between Generations." Journal of Marriage and the Family, 39: 83-93.

Pollard, M.S. \& Wu, Z. 1998. "Divergence of Marriage Patterns in Quebec and Elsewhere in Canada." Population and Development Review, 24: 329-356.

Pope, H. \& Mueller, C.W. 1976. "The Intergenerational Transmission of Marital Instability: Comparisons by Race and Sex." Journal of Social Issues, 32(1): 49-66. 
The Consequences of Parental Divorce on the Life Course Outcomes of Canadian Children

Statistics Canada. 1997a. 1995 General Social Survey (GSS). Cycle 10: The Family. Public Use Microdata File Documentation and User's Guide. Ottawa.

Statistics Canada. 1997b. "1996 Census: Marital Status, Common Law Unions and Families" The Daily, October 14: 2-8.

Statistics Canada. 2002. "Divorces". The Daily, December 2: 9-11.

Stevens-Long, J. \& Cobb, J.N. 1983. Adolescence and Early Adulthood. California State University, Los Angeles: Mayfield Publishing Company.

United Nations 1997. Demographic Yearbook, 1970-1995. New York: United Nations.

Wolfinger, N. 1999. "Trends in the Intergenerational Transmission of Divorce." Demography, 36: 415-420.

Wu, Z. 2000. Cohabitation. An alternative Form of Family Living. Oxford: University Press.

\section{Internet site:}

www.statcan.ca: Canadian Statistics - Population by Religion, 1991 Census. 